\title{
Management of Forearm Bone Gap Non-Unions by Ilizarov Technique
}

\author{
*Bari MM${ }^{1}$, Shahidul Islam² ${ }^{2}$ N.H Shetu ${ }^{3}$ and Mahfuzer Rahman ${ }^{4}$ \\ Chief consultant, Bari-Ilizarov Orthopaedic Centre, Visiting and Honored Professor of ilizarov center Kurgan, Russia
}

Submission: October 20, 2016; Published: November 01, 2016

*Corresponding author: Md Mofakhkharul Bari, Bari-Ilizarov Orthopaedic Centre, 72, Satmasjid Road, Nizams Shankar Plaza, Dhanmondi, Dhaka, Bangladesh, Tel: +8801819211595; Email: bari.ilizarov31@gmail.com

\section{Abstract}

Purpose of the study: Proper treatment of forearm bone gap non-union should achieve both biological stimulation of the bone and elastic mechanical stability. The use of Ilizarov technique enhances the healing of a non-union providing osteogenic, osteoconductive and an optimal stability of Ilizarov fixation. We retrospectively reviewed 26 patients affected by forearm bone non-union and treated with Ilizarov fixation.

Materials and Methods: 26 patients were treated for gap non-unions of forearm bones with Ilizarov compression distraction device from 2000 to 2015 in BARI-ILIZAROV ORTHOPAEDIC CENTRE.

Results: All the difficult non-unions healed in a mean of 7 months ranging from 5 to 12 months. At the latest follow up forearm function were satisfactory.

Conclusion: The Ilizarov compression distraction device is a fantastic tool in promoting the healing of forearm non-unions, even the bones are very atrophic.

Keywords: Forearm bone non-union; Distraction osteogenesis; Ilizarov Techniqu

\section{Introduction}

Different factors like fracture location and complexity, patient characteristics and surgical intervention are involved in the development of forearm bone non union [1,2]. Radius and ulna non-unions are usually associated with complex injury, inadequate initial reduction, unstable fixation. Anatomical and functional relationships between radius and ulna are so peculiar that it represents a sophisticated functional unit. That's why fractures of the radius and ulna should be considered like articular fractures [3].

The function of the forearm is to assist the hand in space positioning and to support the hand movements. Pronation and supination of the forearm occurs at the radio humeral, proximal radio ulnar, and distal radio ulnar joints. Failure of the relationship between radius and ulna due to changes in the length impairs the forearm function and the ability to position the hand in space. When non-union occurs in the forearm bones it impairs forearm, elbow and wrist motion. In these cases fracture healing is a necessary condition to recover a physiological function the upper limb.

Based on the characteristic of the bone ends, aseptic nonunion can be distinguished into atrophic and hypertrophic [4]. Adequate treatment of forearm bone non-union must be considered providing with biological stimulation and elastic mechanical stability by Ilizarov technique. Ilizarov fixator has osteogenesis, osteo conduction, osteo induction, mechanical properties and vascularity [5].

Autologous bone graft is the transplantation of bone of the same individual from an anatomical donor site to one receiver Compared to auto graft, allograft are easier to use, require less surgical time and are potentially unlimited in amount, although allograft presents disadvantages such as higher risk of infection, viral disease transmission and the need of a bone bank available to the hospital $[6,7]$. 
The aim of this study was to show the treatment of gap nonunions of forearm bones by Ilizarov technique through distraction osteogenesis without bone grafting. We retrospectively reviewed 26 patients determining the use of Ilizarov in terms of
A. Rate of healing of non-unions without grafting.
B. Time of healing and
C. Functional results

\section{Materials and Methods}

From 2000 to 2015 a total of 26 patients have non unions of forearm bones with Ilizarov compression-distraction device. We consider a non-union "Arrest of bony fractures repair process with the formation of fibrous or cartilaginous tissue in between the main fragments and fracture has remain un-united for 6-9 months due to mechanical or biological failure judged by clinical and radiological evidence".

\section{Exclusion criteria were}

a. Presence of other fractures in the same limb at the time of the primary forearm injury and

b. Septic non-union.

The initial treatment of the fracture which evolved into nonunion consisted of open reduction and internal fixation with plate and screws, intramedullary rods, external fixation or cast immobilization (Table 1).

Table 1: Fracture and treatment.

\begin{tabular}{|c|c|}
\hline Fracture & Treatment \\
\hline Initial fracture & 05 \\
\hline Radius & 06 \\
\hline Ulna & 15 \\
\hline Initial treatment & \\
\hline Plate and screw fixation & 10 \\
\hline Intramedullary rod & 05 \\
\hline External fixation & 02 \\
\hline Cast immobilization & 09 \\
\hline
\end{tabular}

We treated all the 26 patients by Ilizarov technique. All patients were checked monthly until there was radiological evidence of bone healing. To evaluate the time of healing of the fractures, a combined clinical and radiographic assessment was used. The clinical parameter evaluated were

a. Absence of pain or tenderness on palpation

b. Absence of pain or grip strength

c. Full range of motion at the adjacent joint.

The x-ray parameters used were- ii. Bridging of the fracture seen at three cortices and

iii. Obliteration of the fractures line or cortical continuity.

Non-union evolved in radius done in 5 patients, in ulna 6 patients, and non- union of radius and ulna evolved in 15 patients (Table 2).

Table 2: Non-union characteristics.

\begin{tabular}{|c|c|c|}
\hline Type of & Atrophic gap & Hypertrophic \\
\hline non-union & non-union & non-union \\
\hline Radius & 4 & 1 \\
\hline Ulna & 5 & 1 \\
\hline Radius \& Ulna & 13 & 2 \\
\hline
\end{tabular}

\section{Results}

No per-operative complications occurred. There was no early or late infection. All the non-unions healed. Average time of healing of non-union was 7 months, ranging from 5-12 months (Figures 1-4). Patients resumed ADLs (activity of daily living) 12 days after surgery with Ilizarov apparatus (Figures 5-8).
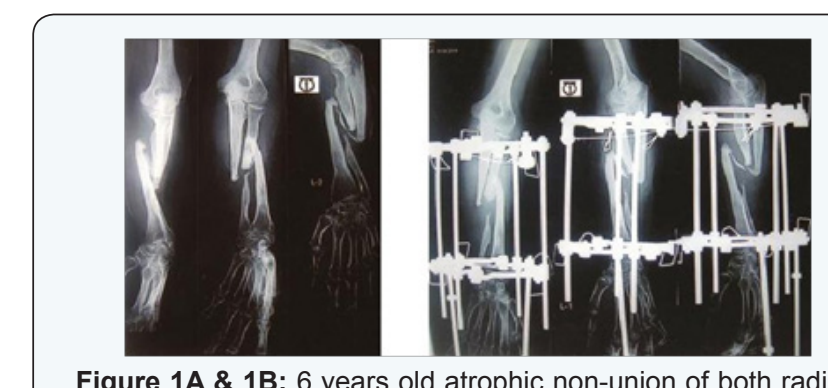

Figure 1A \& 1B: 6 years old atrophic non-union of both radius and ulna (left side) and Distraction by two rings for release of soft tissue contractures.

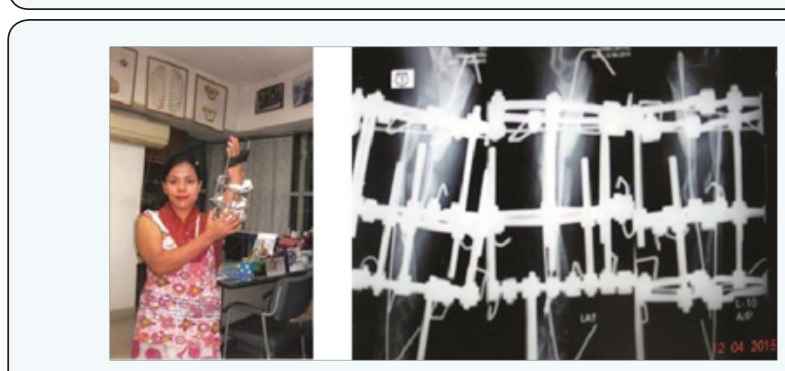

Figure 2A \& 2B: Clinical appearance of the patient with llizarov fixator in the left forearm and Distraction osteogenesis by llizarov technique.

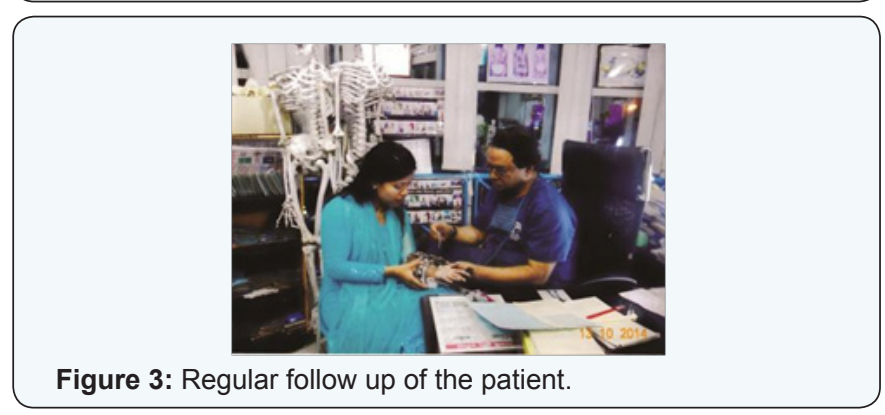

i. New regenerate bone formation 


\section{Orthopedics and Rheumatology Open Access Journal}

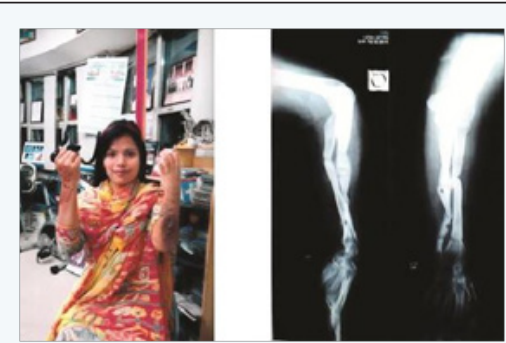

Figure 4: Clinical appearance of the patient after 9 months with good hand function and Patients resumed ADLs (activity of daily living) 12 days after surgery with llizarov apparatus.

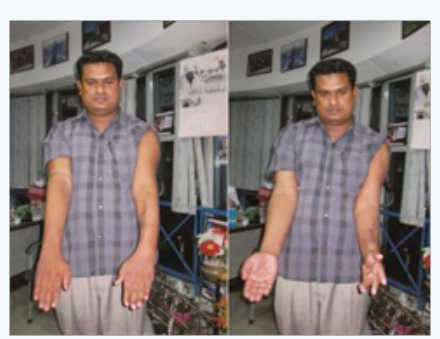

Figure 5: Deformed left forearm before surgery.

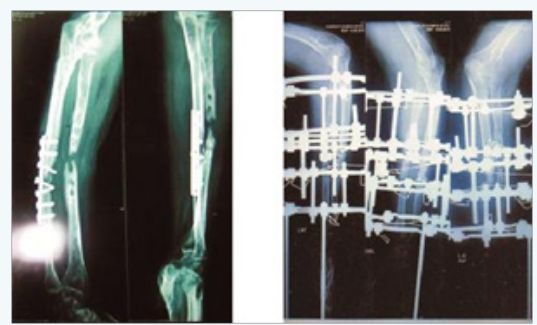

Figure 6a \& 6b: Non-union left ulna with implant failure, atrophic gap non-union left radius; During treatment with llizarov apparatus.
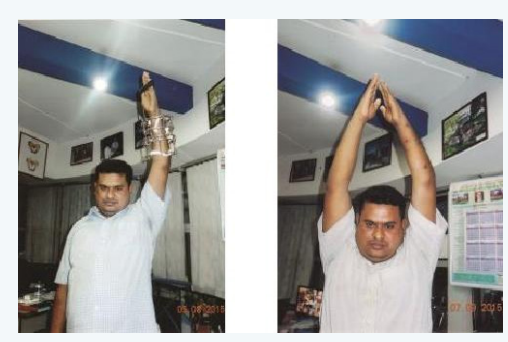

Figure 7a \& 7b: llizarov in the left forearm; Full function with straight left forearm.

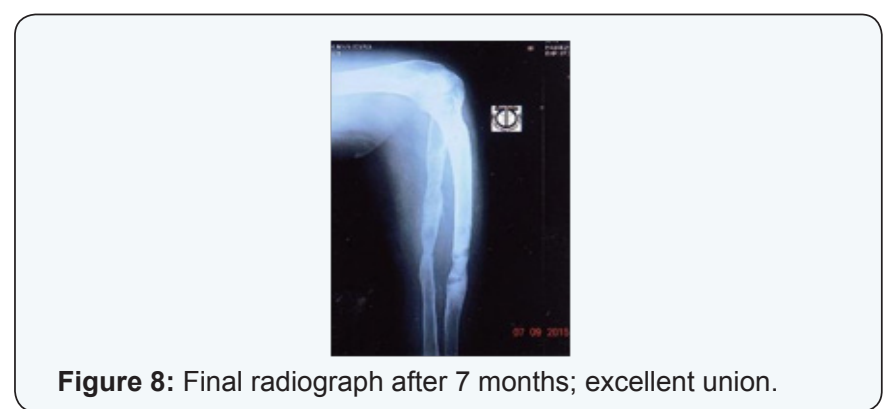

\section{Discussion and Conclusion}

Non-union of forearm bones are difficult to treatment. Ilizarov fixation technique in forearm bone non-union have been shown to be secure to achieve new regenerate bone in the big gap union of radius and ulna by distraction osteogenesis. In atrophic non-union our goal must be the restoration of a good biological environment. Han et al. [8], and Jupiter [9] reported higher success rates using vascularised bone graft which requires longer surgical time and specialized equipment. But Ilizarov compression-distraction technique [10] requires a demanding post-operative care. Higher success rate was achieved in forearm alignment and function with Ilizarov technique. $5 \mathrm{~cm}$ and more gaps with atrophic non-union of forearm bones are difficult to treatment without Ilizarov technique. We found the excellent rate of gap healing and no rate of infection in our series due to distraction osteogenesis.

\section{References}

1. Bari MM (2013) A color atlas of limb lengthening, surgical reconstruction and deformity correction by Ilizarov technique. 127134.

2. Kloen P, Buijze GA, Ring D (2012) Management of forearm nonunions: current concepts. Strategies Trauma Limb Reconstr 7(1): 1-11.

3. Richard MJ, Ruch DS, Aldridge JM (2007) Mal unions and non-unions of the forearm. Hand Clin 23(2): 235-243.

4. Gianmdis PV, Enhom TA Marsn D (2007) Fracture healing: the diamond concept. Injury 38(Suppl 4): S3-S6.

5. Khan SN, Cammisa FP, Sandhu HS, Diwan AD, Girardi FP, et al. (2005) The biology of bone grafting. J Am Acad Orthop Surg 13(1): 77-86.

6. Stevenson $S$ (1998) Enhancement of fracture healing with autogenous and allogeneic bone grafts. Clin Orthop 355(suppl): S239-S246.

7. Faldini, C, Miscione, MT, Acri, F, Chehrassan M, Bonomo M, et al. (2011) Use of homologous bone graft in the treatment of aseptic forearm nonunion. Musculoskeletal Surgery 95(1): 31-35.

8. Han CS, Wood MB, Bishop AT, Cooney WP (1992) Vascularized bone transfer. J Bone Joint Surg Am 74: 1441-1449.

9. Jupiter JB (1990) Complex non-union of the humeral diaphysis. Treatment with a medial approach, an anterior plate, and a vascularized fibular graft. J Bone Joint Surg Am 72(5): 701-707.

10. Ilizarov GA, Kaplunov AG, Degtarev VE, Ledaiev VI (1972) Treatment of pseudarthroses and ununited fractures complicated by purulent infection dry the method of compression-distraction osteogenesis. Ortop Travmatol Protez 33: 10-14.

\begin{tabular}{|l|}
\hline \multicolumn{1}{|c|}{ Your next submission with JuniperPublishers } \\
will reach you the below assets \\
- Quality Editorial service \\
. Swift Peer Review \\
- Reprints availability \\
- E-prints Service \\
- Manuscript Podcast for convenient understanding \\
- Global attainment for your research \\
- Manuscript accessibility in different formats \\
( Pdf, E-pub, Full Text, audio) \\
- Unceasing customer service \\
Track the below URL for one-step submission \\
http://juniperpublishers.com/online-submission.php \\
\hline
\end{tabular}

